\title{
Pencegahan Dan Pemberantasan Peredaran Narkoba Di Indonesia
}

\section{Bayu Puji Hariyanto*}

* Mahasiswa Program Magister (S2) IImu Hukum Fakultas Hukum UNISSULA Semarang, email bayupujihariyanto67@gmail.com

\begin{abstract}
ABSTRAK
Penyalahgunaan narkoba masih menjadi masalah kronis yang menimpa Indonesia, kasus peredaran sabu dan banyak tertangkapnya bandar-bandar narkoba internasional dalam beberapa tahun terakhir menjadi bukti bahwa Indonesia sedang berada dalam kondisi darurat narkoba. Pemerintah Indonesia mengedepankan peran Kepolisian dan Badan Narkotika Nasional (BNN) dalam rangka mencegah dan memberantas peredaran Narkoba di Indonesia. Adapun upaya pencegahan dan pemberantasan Narkoba dilakukan dengan tiga tahapan yaitu pertama, Preemtif yaitu upaya pencegahan yang dilakukan secara dini. Kedua, Preventif yaitu upaya yang sifatnya strategis dan merupakan rencana aksi jangka menengah dan jangka panjang, namun harus dipandang sebagai tindakan yang mendesak untuk segera dilaksanakan. Ketiga, Represif, merupakan upaya penanggulangan yang bersifat tindakan penegakan hukum mulai yang dilakukan oleh intelijen.

Kata Kunci: Pencegahan, Pemberantasan, Peredaran Narkoba.
\end{abstract}

\section{ABSTRACT}

The drug abuse is still become a chronical problem that afflicts Indonesia, the case of methamphetamine circulation and so many international drug dealers that caught in a few years ago becoming an evidence that Indonesia is on a state of drug emergency. The Indonesian Government placing the role of National Police and National Narcotics Agency forward in order to preventing and eradicating of drug by doing a three steps which is first, Pre-emptive, which is prevention that implemented early. Second, Preventive, which is an effort that strategically and a medium and long term action plan, but should also be seen as an action that urgently implemented. Third, Represive, is an effort of countermeasure as a start of law enforcement conducted by intelligence.

Keywords: Prevention, Eradication, Drug Circulation

\section{PENDAHULUAN}

Penyalahgunaan narkoba di Indonesia beberapa tahun terakhir ini menjadi masalah serius dan telah mencapai keadaan yang memprihatinkan, sehingga permasalahan narkoba menjadi masalah nasional. Sebagai salah satu negara berkembang, Indonesia menjadi sasaran yang sangat potensial sebagai tempat pengedaran narkoba secara ilegal. Penyalahgunaan narkoba masih menjadi masalah kronis yang menimpa Indonesia, kasus peredaran sabu dan banyak tertangkapnya bandar-bandar narkoba internasional dalam beberapa tahun terakhir menjadi bukti bahwa Indonesia sedang berada dalam kondisi darurat narkoba.

Indonesia juga menjadi sasaran bagi para pengedar narkoba, karena di Indonesia para pengedar narkoba bisa menjual barang haram tersebut dengan mudah karena masih kurangnya 
pengawasan. Penyalahgunaan narkoba serta peredarannya yang telah mencapai seluruh penjuru daerah dan tidak lagi mengenal strata sosial masyarakat, penyalahgunaan narkoba saat ini tidak hanya menjangkau kalangan yang tidak berpendidikan saja akan tetapi penyalahgunaan narkoba telah menyebar di semua kalangan bahkan sampai pada kalangan berpendidikan. Selain itu, pengawasan pemerintah yang lemah terhadap pengedaran narkoba pun membuat pengedar narkoba semakin mudah untuk menjalankan transaksinya.

Kehidupan di jaman modern sangat jauh dari kata ramah, hal ini terlihat dari tingginya tingkat kesibukan masyarakat, tingginya angka depresi, banyaknya anak-anak yang kurang perhatian orang tua, dan begitu beragamnya kegiatan yang dilakukan sampai dengan ramainya kegiatan di jam-jam malam, ini terlihat dari banyaknya tempat hiburan malam yang buka dan berkembang. Hal ini sangat mempengaruhi pola kehidupan masyarakat, salah satunya adalah keberadaan obat bius dan zat-zat narkotika. ${ }^{1}$

Peredaran narkoba yang dilakukan dengan teknik canggih telah merambah seluruh Indonesia. Dapat dikatakan terjadi perubahan modus dari para sindikat, dimana khusus jenis psikotropika tidak lagi diimpor namun pengedarnya lebih memilih membuat pabrik untuk memproduksi sendiri. Pengadaan bahan baku, peracikan, hingga perekrutan orang terkait pembagian tugas dalam memproduksi narkoba benar-benar direncanakan dengan baik. Hal ini dapat dikatakan ketika melihat tren kasus pabrik-pabrik narkotik yang terus bermunculan. Tindak pidana narkotika telah bersifat transnasional yang dilakukan dengan menggunakan modus operandi yang tinggi, teknologi yang canggih, didukung oleh jaringan organisasi yang luas, dan sudah banyak menimbulkan korban terutama di kalangan generasi muda yang sangat merugikan kehidupan masyarakat, bangsa, dan negara.

Indonesia yang pada mulanya sebagai Negara transit perdagangan narkoba, kini sudah dijadikan daerah tujuan operasi oleh jaringan Narkoba Internasional. Tingginya angka penyalahgunaan narkoba tersebut juga disumbang oleh ulah pada sindikat narkoba. Sebagian besar penyalahgunaan berada pada kelompok coba pakai terutama pada kelompok pekerja. Alasan penggunaan Narkoba karena pekerjaan yang berat, kemampuan sosial ekonomi, dan tekanan lingkungan teman kerja merupakan faktor pencetus terjadinya penyalahgunaan Narkoba pada kelompok pekerja.

Proses perubahan sosial yang tengah berlangsung di Indonesia menandai pula perkembangan kota-kota dengan kompleksitas fungsinya yang tidak lagi hanya mempunyai fungsi administratif dan komersial, melainkan tumbuh sebagai simpul interaksi sosial yang mempengaruhi sistem nilai dan norma serta perilaku warga masyarakat. Peraturan perundangundangan hadir dimana hukum berfungsi sebagai pengendali sosial (social control), memaksa warga masyarakat untuk mematuhi peraturan perundang-undangan yang berlaku. Undangundang yang mengatur mengenai narkotika sebagai hukum yang wajib ditaati, karena dibentuk atas kerjasama antara wakil-wakil rakyat dengan pemerintah. Ini artinya telah ada kesepakatan antara rakyat dengan pemerintah tentang peraturan narkotika, yang sama-sama harus ditaati oleh semuanya. Adapun tujuannya, agar hukum dapat diberlakukan dengan lancar sesuai dengan tujuan yang diharapkan.

Kepolisian Republik Indonesia (Polri) sebagai garda depan dalam perang melawan narkoba di Indonesia terus membuktikan kemampuannya untuk memenangi perang tersebut. Peran penting pihak kepolisian dalam tugasnya memberantas kasus kejahatan terkait narkoba harus didukung

\footnotetext{
${ }^{1}$ Julianan Lisa FR, Nengah Sutrisna W, Narkotika,Psikotropika dan gangguan jiwa, Nuha Medika,Yoygakarta, 2013, hal.2.
} 
dengan baik walaupun angka-angka kasus tersebut tetap meningkat. Terungkapnya kasus-kasus di satu sisi memang dapat menjadi indikator meningkatnya kerja polisi dalam memburu sindikat peredaran narkoba, namun di sisi lain dapat memberi petunjuk betapa kebijakan pemerintah saat ini lemah dalam menghadapi peredaran tersebut. Jadi, walaupun Indonesia memiliki UndangUndang Nomor 5 tahun 1997 tentang psikotropika dan Undang-Undang Nomor 22 Tahun 1997 tentang narkotika yang telah diganti menjadi Undang-Undang Nomor 35 tahun 2009 Tentang Narkotika, namun masalah tindak pidana kejahatan ini belum dapat diselesaikan dengan tuntas.

Dalam Undang-Undang Nomor 35 tahun 2009 Tentang Narkotika ini diatur juga peran BNN (Bandan Narkotika Nasional) yang ditingkatkan menjadi lembaga pemerintah non kementerian (LPNK) dan diperkuat kewenangannya untuk melakukan penyelidikan dan penyidikan. BNN (Bandan Narkotika Nasional) berkedudukan dibawah Presiden, BNN (Bandan Narkotika Nasional) juga mempunyai perwakilan di daerah provinsi dan kabupaten/kota sebagai instansi vertikal (Badan Narkotika Provinsi atau Badan Narkotika Kota). Serta mengatur peran masyarakat dalam usaha pencegahan dan pemberantasan penyalahgunaan narkotika dan prekursor narkotika termasuk pemberian penghargaan bagi anggota masyarakat yang berjasa dalam upaya pemberantasan penyalahgunaan narkotika dan prekursor narkotika.

Kinerja dua Lembaga Negara yaitu Polri dan BNN dalam memberantas peredaran Narkoba di Indonesia tidak perlu diragukan lagi. Terbukti dalam beberapa tahun terakhir pengungkapan yang dilakukan oleh dua Lembaga Negara ini menunjukan prestasi yang luar biasa bagi Indonesia. Polri sendiri berhasil menggagalkan pengiriman 1 (satu) ton sabu-sabu yang dilakukan oleh 5 (lima) orang warga negara asing dari Taiwan dengan modus mengangkut barang haram tersebut menggunakan Kapal Wisata Berlabel Wanderlust di Anyer, Banten. Sementara BNN juga berhasil mengungkap penyelundupan Narkoba jaringan internasional yang melibatkan 4 (empat) orang Warga Negara Hongkong dan 1 (satu) orang Warga Negara Malaysia, dimana dari kelima warga negara asing ini BNN berhasil menyita $840 \mathrm{~kg}$ sabu-sabu asal Guangzhou, Tiongkok.

Kejahatan narkoba merupakan kejahatan International (International Crime), kejahatan yang terkoorganisir (Organize Crime), mempunyai jaringan yang luas, mempunyai dukungan dana yang besar dan sudah menggunakan teknologi yang canggih. Narkoba mempunyai dampak negatif yang sangat luas, baik secara fisik, psikis, ekonomi, sosial, budaya, hankam, dan lain sebagainya. Bila penyalahgunaan narkoba tidak diantisipasi dengan baik, maka akan rusak bangsa dan negara ini. Oleh karena itu, diperlukan kerja sama yang baik dari seluruh komponen bangsa untuk penanggulangan penyalahgunaan narkoba. ${ }^{2}$

Upaya pemberantasan tindak pidana penyalahgunaan narkotika telah dilakukan oleh berbagai pihak seperti kepolisian, BNN, maupun lembaga swadaya masyarakat. Polri dan BNN telah merilis berbagai upaya pemberantasan tindak pidana penyalahgunaan narkotika yang dilakukan secara prefemtif, preventif, dan represif dengan tujuan agar Negara Indonesia bebas Narkoba.

\section{PEMBAHASAN}

\section{Pengertian Narkoba}

Narkoba adalah singkatan dari narkotika, psikotropika dan bahan adiktif lainnya. Narkoba adalah obat, bahan, atau zat dan bukan tergolong makanan jika diminum, diisap, dihirup, ditelan atau disuntikkan, berpengaruh terutama pada kerja otak (susunan syaraf pusat), dan sering

\footnotetext{
${ }^{2}$ Soedjono A., Patologi Sosial, Bandung: Alumni, 2000, hal. 41.
} 
menyebabkan ketergantungan. Akibatnya kerja otak berubah (meningkat atau menurun), demikian juga fungsi vital organ tubuh lain ( jantung, peredaran darah, pernapasan dan lainnya). ${ }^{3}$

Sesuai dengan Undang-Undang Narkoba Nomor 35 Tahun 2009 tentang Narkotika, Narkoba dibagi dalam 3 jenis yaitu Narkotika, Psikotropika dan Zat adiktif lainnya.

1. Narkotika

Menurut Soerdjono Dirjosisworo (1986) bahwa pengertian narkotika adalah "Zat yang bisa menimbulkan pengaruh tertentu bagi yang menggunakannya dengan memasukkan kedalam tubuh." Pengaruh tersebut bisa berupa pembiusan, hilangnya rasa sakit, rangsangan semangat dan halusinasi atau timbulnya khayalan-khayalan. Sifat-sifat tersebut yang diketahui dan ditemukan dalam dunia medis bertujuan dimanfaatkan bagi pengobatan dan kepentingan manusia di bidang pembedahan, menghilangkan rasa sakit dan lain-lain. Narkotika digolongkan menjadi 3 kelompok yaitu:

a. Narkotika golongan I, adalah narkotika yang paling berbahaya. Daya adiktifnya sangat tinggi. Golongan ini digunakan untuk penelitian dan ilmu pengetahuan. Contoh : ganja, heroin, kokain, morfin, dan opium.

b. Narkotika golongan II, adalah narkotika yang memiliki daya adiktif kuat, tetapi bermanfaat untuk pengobatan dan penelitian. Contoh : petidin, benzetidin, dan betametadol.

c. Narkotika golongan III, adalah narkotika yang memiliki daya adiktif ringan, tetapi bermanfaat untuk pengobatan dan penelitian. Contoh: kodein dan turunannya.

2. Psikotropika

Pengertian Psikotopika adalah zat atau obat bukan narkotika, baik alamiah maupun sintesis, yang memiliki khasiat psikoaktif melalui pengaruh selektif pada susunan saraf pusat yang menyebabkan perubahan khas pada aktivitas normal dan perilaku. Psikotropika digolongkan lagi menjadi 4 kelompok adalah :

a. Psikotropika golongan I, adalah dengan daya adiktif yang sangat kuat, belum diketahui manfaatnya untuk pengobatan dan sedang diteliti khasiatnya. Contoh: MDMA, LSD, STP, dan ekstasi.

b. Psikotropika golongan II, adalah psikotropika dengan daya adiktif kuat serta berguna untuk pengobatan dan penelitian. Contoh : amfetamin, metamfetamin, dan metakualon.

c. Psikotropika golongan III,adalah psikotropika dengan daya adiksi sedang serta berguna untuk pengobatan dan penelitian. Contoh : lumibal, buprenorsina, dan fleenitrazepam.

d. Psikotropika golongan IV, adalah psikotropika yang memiliki daya adiktif ringan serta berguna untuk pengobatan dan penelitian. Contoh : nitrazepam (BK, mogadon, dumolid) dan diazepam.

3. Zat adiktif lainnya

Zat adiktif lainnya adalah zat-zat selain narkotika dan psikotropika yang dapat menimbulkan ketergantungan pada pemakainya, diantaranya adalah :

a. Rokok

b. Kelompok alkohol dan minuman lain yang memabukkan dan menimbulkan ketagihan.

c. Thiner dan zat lainnya, seperti lem kayu, penghapus cair dan aseton, cat, bensin yang bila dihirup akan dapat memabukkan. (Alifia, 2008). ${ }^{4}$

\footnotetext{
${ }^{3}$ Sri Rejeki, “Penanggulangan Narkoba Di Kalangan Remaja”, Majalah Ilmiah Pawiyatan, Vol: XXI, No: 1, (2014), url: http://download.portalgaruda.org/article.php. hal. 23.

${ }^{4}$ Alifia, U, Apa Itu Narkotika dan Napza, Semarang: PT Bengawan IImu, 2008, hal. 25.
} 


\section{Peredaran Narkoba Di Indonesia}

Peredaran narkoba di Indonesia kondisinya sudah mengkhawatirkan. Hal ini berdasarkan data yang dikeluarkan oleh POLRI dimana angka kasus peredaran narkoba di Indonesia mengalami peningkatan sebagai berikut: pada tahun 2010 jumlah kasus narkoba berjumlah 17.384 kasus dengan jumlah tersangka sebesar 23.900; pada tahun 2011 terjadi peningkatan kasus menjadi sebanyak 19.045 dengan jumlah tersangka sebanyak 25.154; pada tahun 2012 jumlah kasus sebesar 18.977 dengan jumlah tersangka sebanyak 25.122; pada tahun 2013 berjumlah 21.119 kasus dengan total 28.543 tersangka; serta pada tahun 2014 terdapat sebesar 22.750 kasus dengan jumlah tersangka sebanyak 30.496 (Bareskrim POLRI, 2015).

Maraknya peredaran narkoba di Indonesia dikarenakan banyaknya pelabuhan tidak resmi atau biasa dikenal dengan pelabuhan tikus yang dijadikan sebagai tempat favorit bagi pelaku pengedar narkoba. Terdapat beberapa cara yang dilakukan oleh pelaku dalam melakukan transaksi narkoba, antara lain yaitu face to face, transaksi melalui kurir, pembelian langsung ke lokasi peredaran narkoba, sistem tempel (sistem tanam ranjau), serta sistem lempar lembing. Sumber narkoba yang beredar di Indonesia kebanyakan berasal dari luar negeri seperti Asia, Eropa, Afrika dan Amerika.

Terdapat berbagai cara bagaimana narkoba dapat masuk ke wilayah Indonesia. Ada yang masuk ke Indonesia langsung dari negara asalnya, ada pula yang masuk ke Indonesia dengan cara transit lebih dulu ke Malaysia, untuk kemudian dibawa ke Indonesia. Jalur yang ditempuh dari negara transit ini juga bermacam-macam. Bisa melalui jalur udara, jalur laut, sungai, maupun dari darat melalui wilayah perbatasan. Jalur laut dan jalur sungai paling banyak dimanfaatkan oleh pelaku untuk didistribusikan ke berbagai wilayah, dikarenakan banyaknya pelabuhan kecil yang tersebar di berbagai provinsi (Kalimantan, Sumatera, dan Papua) serta kurangnya pengawasan oleh aparat di daerah tersebut. ${ }^{5}$ Kurangnya sumber daya manusia serta sarana prasarana yang kurang memadai menjadi faktor lemahnya pengawasan terhadap jalur laut dan sungai.

\section{Polri (Kepolisian Negara Republik Indonesia)}

Pengertian kepolisian juga terdapat dalam Undang-Undang di Indonesia. Undang-undang yang membahas tentang Kepolisian Negara Republik Indonesia terdapat dalam Undang-Undang No 2 Tahun 2002 dalam Pasal 1 ayat (1). Dalam Undang-Undang Nomor 2 Tahun 2002 Pasal 1 ayat (1) menyebutkan bahwa "Kepolisian adalah segala hal-ihwal yang berkaitan dengan fungsi dan lembaga polisi sesuai dengan peraturan perundang-undangan; Anggota Kepolisian Negara Republik Indonesia adalah pegawai negeri pada Kepolisian Negara Republik Indonesia. Fungsi kepolisian sebagai salah satu fungsi pemerintahan negara di bidang pemeliharaan keamanan dan ketertiban masyarakat, penegakan hukum, pelindung, pengayom dan pelayanan kepada masyarakat. Sedangkan lembaga kepolisian adalah organ pemerintah yang ditetapkan sebagai suatu lembaga dan diberikan kewenangan menjalankan fungsinya berdasarkan peraturan perundang-undangan. Polri dalam upaya pencegahan dan penanggulangan penyalahgunaan narkoba, melakukan langkah strategis sebagai berikut:

a. Pre-emptif

Upaya pre-emptif yang dilakukan adalah berupa kegiatan-kegiatan edukatif

\footnotetext{
${ }^{5}$ Apriliantin Putri Pamungkas, "Peran ASEANAPOL dalam Pemberantasan Peredaran Narkoba di Indonesia", Journal of International Relations, Volume 3, Nomor 2, (2017), url: http://ejournal-s1.undip.ac.id/index.php/jihi, hal. 93.
} 
(pendidikan/pengajaran) dengan tujuan mempengaruhi faktor-faktor penyebab yang mendorong dan faktor peluang,yang biasa disebut faktor "korelatif kriminologen" dari kejahatan narkotika, sehingga tercipta suatu kesadaran, kewaspadaan, daya tangkal, serta terbina dan terciptanya kondisi perilaku/norma hidup bebas Narkoba. Yaitu dengan sikap tegas untuk menolak terhadap kejahatan Narkoba. Kegiatan ini pada dasarnya berupa pembinaan dan pengembangan lingkungan pola hidup sederhanadan kegiatan positif,terutama bagi remaja dengan kegiatan yang bersifat produktif, konstraktif, dan kreatif. Sedangkan kegiatan yang bersifat preventif edukatif dilakukan dengan metode komunikasi informasi edukatif, yang dilakukan melalui berbagai jalur antara lain keluarga, pendidikan, lembaga keagamaan, dan organisasi kemasyarakatan.

b. Preventif

Upaya ini dilakukan untuk mencegah terjadinya kejahatan Narkoba melalui pengendalian dan pengawasan jalur resmi serta pengawasan langsung terhadap jalur-jalur peredaran gelap dengan tujuan agar Police Hazard tidak berkembang menjadi ancaman faktual.

c. Represif

Upaya Represif atau penindakan dilakukan dengan cara melakukan penangkapanpenangkapan terhadap para pengguna dan pengedar narkoba. Penangkapan tidak hanya dilakukan terhadap warga negara Indonesia saja, tetapi penangkapan juga dilakukan terhadap warga negara asing yang terlibat. ${ }^{6}$

\section{Badan Narkotika Nasional}

Badan Narkotika Nasional (BNN) adalah lembaga pemerintah non kementerian yang berkedudukan di bawah dan bertanggung jawab kepada Presiden melalui koordinasi Kepala Kepolisian Negara Republik Indonesia. Dalam melaksanakan tugas pemberantasan penyalahgunaan dan peredaran gelap Narkotika dan Prekursor Narkotika, Badan Narkotika Nasional berwenang melakukan penyelidikan dan penyidikan penyalahgunaan dan peredaran gelap narkotika dan prekursor narkotika. Badan Narkotika Nasional (BNN) juga bertugas menyusun dan melaksanakan kebijakan nasional mengenai pencegahan dan pemberantasan penyalahgunaan dan peredaran gelap psikotropika, prekursor, dan bahan adiktif lainnya kecuali bahan adiktif untuk tembakau dan alkohol.

Dalam melaksanakan tugas pemberantasan penyalahgunaan dan peredaran gelap Narkotika dan Prekursor Narkotika, Badan Narkotika Nasional (BNN) berwenang melakukan penyelidikan dan penyidikan penyalahgunaan dan peredaran gelap Narkotika dan Prekursor Narkotika. Keberadaan badan narkotika nasional sesuai dengan Keppres RI No.17/2002 tanggal 22 maret 2002, dalam rangka penanggulangan dan pemberantasan peredaran gelap narkotika, kiranya harus lebih aktif mengkoordinasikan instansi pemerintah terkait dalam penyusunan kebijakan dan pelaksanaan dibidang ketersediaan, pencegahan dan pemberantasan penyalahgunaan dan peredaran gelap narkotika, psykotropika, precursor dan aditif lainnya.

Tugas Badan Narkotika Nasional (BNN) disebut dalam Pasal 70 UU 39 tahun 2009 dan Pasal

2 Perpres No. 23 tahun 2010, sebagai berikut:

a. Menyusun dan melaksanakan kebijakan nasional mengenai pencegahan dan pemberantasan penyalahgunaan dan peredaran gelap narkotika dan prekursor narkotika.

b. Mencegah dan memberantas penyalahgunaan dan peredaran gelap narkotika dan prekursor narkotika.

\footnotetext{
${ }^{6}$ Undang-Undang Nomor 2 Tahun 2002 tentang Kepolisian Negara Republik Indonesia.
} 
c. Berkoordinasi dengan Kepala Kepolisian Republik Negara Indonesia dalam pencegahan dan pemberantasan penyalahgunaan dan peredaran gelap narkotika dan prekursor narkotika.

d. Meningkatkan kemampuan lembaga rehabilitasi medis dan rehabilitasi sosial pecandu narkotika, baik yang diselenggarakan oleh pemerintah maupun masyarakat.

e. Memberdayakan masyarakat dalam pecegahan penyalahgunaan dan peredaran gelap narkotika dan prekursor narkotika.

f. Memantau, mengarahkan, dan meningkatkan kegiatan masyarakat dalam pencegahan penyalahgunaan dan peredaran gelap narkotika dan prekursor narkotika.

g. Melakukan kerja sama bilateral dan multirateral, baik regional maupun internasional, guna mencegah dan memberantas peredaran gelap narkotika dan prekursor narkotika.

h. Mengembangkan laboratorium narkotika dan prekursor narkotika.

i. Melaksanakan administrasi penyelidikan dan penyidikan terhadap perkara penyalahgunaan dan peredaran gelap narkotika dan prekursor narkotika.

j. Membuat laporan tahunan mengenai pelaksanaan tugas dan wewenang.

\section{Upaya Pencegahan dan Pemberantasan Narkoba}

Pencegahan atau penanggulangan penyalahgunaan narkoba merupakan suatu upaya yang ditempuh dalam rangka penegakan baik terhadap pemakaian, produksi maupun peredaran gelap narkotika yang dapat dilakukan oleh setiap orang baik individu, masyarakat dan negara. Pola kebijakan kriminal sebagai upaya penanggulangan kejahatan menurut Arief (2009:23) mengatakan bahwa, dapat ditempuh melalui 3 (tiga) elemen pokok yaitu: penerapan hukum pidana (criminal law application), pencegahan tanpa pidana (prevention without punishment) dan mempengaruhi pandangan masyarakat mengenai kejahatan dan pemidanaan lewat media massa (influencing views of society on crime). ${ }^{7}$ Untuk mengatasi peredaran narkoba di dalam negeri, Pemerintah Indonesia telah mengaturnya melalui Undang-Undang Nomor 35 Tahun 2009 tentang Narkotika. Melalui Undang-Undang ini, pemerintah bertujuan antara lain untuk menjamin ketersediaan narkotika untuk kepentingan pelayanan kesehatan dan/atau pengembangan ilmu pengetahuan dan teknologi; mencegah, melindungi dan menyelamatkan bangsa Indonesia dari penyalahgunaan narkotika; memberantas peredaran gelap narkotika; dan menjamin pengaturan upaya rehabilitasi medis dan sosial bagi penyalahguna dan pecandu narkotika.

Selain menerapkan Undang-Undang Nomor 35 Tahun 2009 tentang Narkotika, pemerintah juga memperkuat aturan hukum tersebut melalui Peraturan Pemerintah Nomor 25 Tahun 2011 tentang Pelaksanaan Wajib Lapor Pecandu Narkotika. Tidak hanya itu, pemerintah juga mengeluarkan Instruksi Presiden No 12 Tahun 2011 tentang Pelaksanaan Kebijakan dan Strategi Nasional Pencegahan dan Pemberantasan Penyalahgunaan dan Peredaran Gelap Narkoba tahun 2011-2015 sebagai bentuk komitmen bersama seluruh komponen masyarakat, bangsa dan negara. Terakhir adalah Peraturan Menteri Dalam Negeri (Permendagri) Nomor 21 Tahun 2013 tentang Fasilitasi Pencegahan dan Penyalahgunaan Narkotika, yang didalamnya melibatkan peran serta dari gubernur/bupati/walikota.

Dalam rangka melakukan upaya pencegahan, pemberantasan dan penanggulangan penyalahgunaan dan peredaran gelap narkotika lintas negara, perlu digunakan pendekatan multi

\footnotetext{
7 Ira Helviza, Zulihar Mukmin dan Amirullah, "Kendala-Kendala Badan Narkotika Nasional (BNN) Dalam Penanggulangan Penyalahgunaan Narkotika di Kota Banda Aceh, Jurnal Ilmiah Mahasiswa Pendidikan Kewarganegaraan Unsyiah Volume1, Nomor 1 (2016), url: https://media.neliti.com/media/publications/187604 hal. 138.
} 
dimensional dengan memanfaatkan berbagai disiplin ilmu pengetahuan dari penerapan teknologi. Sebagaimana diungkapkan oleh Wijaya (2005: 153) mengatakan bahwa, penanggulangan terhadap peredaran gelap dan penyalahgunaan narkotika dapat di tempuh melalui berbagai strategi dan kebijakan pemerintah yang kemudian dilaksanakan secara menyeluruh dan simultan oleh aparat terkait bekerjasama dengan komponen masyarakat anti narkoba. Adapun strategi penanggulangan terhadap peredaran gelap dan penyalahgunaan narkoba adalah sebagai berikut:

1. Strategi Pengurangan Permintaan (Demand Reduction) Narkoba

Strategi pengurangan permintaan meliputi pencegahan penyalahgunaan narkoba. Upaya ini meliputi: ${ }^{8}$

a. Primer atau pencegahan dini.

Yaitu ditujukkan kepada individu, keluarga atau komunitas dan masyarakat yang belum tersentuh oleh permasalahan penyalahgunaan dan peredaran gelap narkoba, dengan tujuan membuat individu, keluarga, dan kelompok untuk menolak dan melawan narkoba.

b. Pencegahan sekunder atau pencegahan kerawanan.

Yaitu ditujukan kepada kelompok atau komunitas yang rawan terhadap penyalahgunaan narkoba. Pencegahan ini dilakukan melalui jalur pendidikan, konseling, dan pelatihan agar mereka berhenti, kemudian melakukan kegiatan positif dan menjaga agar mereka tetap lebih mengutamakan kesehatan.

c. Pencegahan tertier

Yaitu pencegahan terhadap para pengguna/pecandu kambuhan yang telah mengikuti program teraphi dan rehabilitas, agar tidak kambuh lagi.

2. Pengawasan Sediaan (Supply Control) Narkoba

a. Pengawasan Jalur Legal Narkoba

Narkoba dan prekusor untuk keperluan medis dan ilmu pengetahuan serta untuk keperluan industri diawasi oleh pemerintah.Pengawasan jalur legal ini meliputi pengawasan penanaman, produksi, importasi, eksportasi, transportasi penggudangan, distribusi dan penyampaian oleh instansi terkait, dalam hal ini departemen kehutanan.

b. Pengawasan Jalur Ilegal Narkoba

Pengawasan jalur ilegal narkoba meliputi pencegahan di darat, di laut dan di udara. Badan narkotika nasional telah membentuk Airport dan seaport interdiction task force (satuan tugas pencegahan pada kawasan pelabuhan udara dan pelabuhan laut).

3. Pengurangan Dampak Buruk (Harm Reduction) Penyalahgunaan Narkoba.

Sampai saat ini pemerintah secara resmi hanya mengakui dan menjalankan dua strategi yaitu pengurangan permintaan dan pengawasan sediaan narkoba. Namun menghadapi tingginya prevalensi OHD (orang dengan HIV/AIDS) dikalangan penyalahgunaan narkoba dengan jarum suntik secara bergantian, maka pada 8 Desember 2003 BNN telah mengadakan nota kesepahaman dengan KPA (komisi penanggulangan HIV/AIDS), nomor 21 kep/menko/kesra/XII/BNN, yang bertujuan untuk membangin kerjasama antara komisi penganggulangan AIDS (KPA) dengan BNN dalam rangka pencegahan penyebaran HIV/AIDS dalam pemberantasan penyalahgunaan narkotika. ${ }^{9}$

\section{PENUTUP}

\footnotetext{
${ }^{8}$ Yusuf Apandi, Katakan tidak pada narkoba, Bandung: Simbiosa Rekatama Mebia, 2010, hal 22.

9 Wagimin Wira Wijaya, Jurnal Intelijen \& Kontra Intelijen volume II/ Agustus 2005 No. 07. url: https://media.neliti.com/media/publications/187604-ID, hal. 133.
} 


\section{Kesimpulan}

a. Pencegahan dan Pemberantasan Narkoba merupakan usaha-usaha yang telah dilakukan oleh dilakukan oleh Pemerintah dengan mengedepankan Polri dan BNN (Badan Narkotika Nasional), agar dapat mewujudkan sumber daya manusia Indonesia seutuhnya. Adapun upaya pencegahan dan pemberantasan Narkoba dilakukan dengan tiga tahapan yaitu pertama, Preemtif yaitu upaya pencegahan yang dilakukan secara dini. Kedua, Preventif yaitu upaya yang sifatnya strategis dan merupakan rencana aksi jangka menengah dan dangka panjang, namun harus dipandang sebagai tindakan yang mendesak untuk segera dilaksanakan. Ketiga, Represif, merupakan upaya penanggulangan yang bersifat tindakan penegakan hukum mulai yang dilakukan oleh intelijen Kepolisian dalam proses penyidik yang meliputi Pengintaian, penggerbekan, dan penangkapan guna menemukan pengguna maupun pengedar Narkotika beserta bukti-buktinya.

b. Upaya pencegahan dan pemberantasan terhadap penyalahgunaan dan peredaran gelap narkoba perlu dilakukan secara komprehensif dan multidimensional. Sehingga perlu berusaha menghilangkan pandangan bahwa masalah penyalahgunaan dan peredaran gelap narkoba bukan hanya masalah pemerintah saja, tetapi merupakan masalah yang harus ditanggulangi bersama. Pencegahan dan pemberantasan terhadap penyalahgunaan dan peredaran gelap narkoba dilakukan dengan membangun upaya pencegahan yang berbasis masyarakat.

\section{Saran}

a. Perlu adanya kerja sama dengan instansi pemerintahan lain diluar Polri dan BNN (Badan Narkotika Nasional) dalam rangka meningkatkan keberhasilan pencegahan dan pemberantasan peredaran Narkoba di Indonesia.

b. Perlu adanya peran generasi muda dalam rangka mendukung upaya Pemerintah mencegah dan memberantas peredaran Narkoba yang saat ini masih meraja rela di hampir setiap lapisan masyarakat. Peran generasi muda sebagai generasi penerus Bangsa menjadi sangat penting demi keberhasilan membebaskan Negara Indonesia dari darurat Narkoba.

\section{DAFTAR PUSTAKA}

Apandi, Yusuf, 2010, Katakan tidak pada narkoba, Bandung: Simbiosa Rekatama Mebia.

Helviza, Ira, Zulihar Mukmin dan Amirullah, 2016, "Kendala-Kendala Badan Narkotika Nasional (bnn) Dalam Penanggulangan Penyalahgunaan Narkotika di Kota Banda Aceh, Jurnal Ilmiah Mahasiswa Pendidikan Kewarganegaraan Unsyiah Volume1, Nomor 1, url: https://media.neliti.com/media/publications/187604.

Julianan Lisa FR, Nengah Sutrisna W, 2013, Narkotika, Psikotropika dan gangguan jiwa, Yogyakarta: Nuha Medika.

Pamungkas, Apriliantin Putri, 2017, "Peran ASEANAPOL dalam Pemberantasan Peredaran Narkoba di Indonesia", Journal of International Relations, Volume 3, Nomor 2, url: http://ejournal-s1.undip.ac.id/index.php/jihi.

Rejeki, Sri, 2014, "Penanggulangan Narkoba Di Kalangan Remaja”, Majalah IImiah Pawiyatan, Vol: XXI, No: 1, url: http://download.portalgaruda.org/article.php.

Soedjono, A., 2000, Patologi Sosial, Bandung: Alumni 
Jurnal Daulat Hukum Volume 1 No. 1 Maret 2018 : 201 - 210

U, Alifia, 2008, Apa Itu Narkotika dan Napza, Semarang: PT Bengawan Ilmu.

Undang-Undang Nomor 2 Tahun 2002 tentang Kepolisian Negara Republik Indonesia.

Undang-Undang Nomor 35 Tahun 2009 tentang Narkotika

Wijaya, Wagimin Wira, 2005, Jurnal Intelijen \& Kontra Intelijen volume II/ No. 07. url: https://media.neliti.com/media/publications/187604-ID. 